\title{
A General and Facile One-Pot Synthesis of Napthoquinone- 1,3-dithioles in Aqueous Medium
}

\author{
SOUMEN K. MANIK, ARPITA MAITI, SUDHIR C. PAL ${ }^{*}$ and NIRMAL K. HAZRA
}

Department of Chemistry, Egra S. S. B. College, Egra-721429, Purba Medinipur, W.B, India sudhirpal08@gmail.com

Received 11 October 2014 / Accepted 17 October 2014

\begin{abstract}
A general and facile one pot protocol for the preparation of napthoquinone-1,3-dithioles has been developed from the three-component reaction of primary amine, carbon disulfide and 2,3-dichloro-1,4-napthoquinone under aqueous conditions. Both aliphatic and aromatic primary amines were used to get the corresponding products in moderate to excellent yields. Moreover, this method is advantageous over reported methods.
\end{abstract}

Keywords: One-pot synthesis, Napthoquinone-1,3-dithioles, Three component reaction

\section{Introduction}

High yield efficiency and minimum steps are important strategies in synthetic organic chemistry. Combining three or more simple starting materials in a one-pot protocol provides quick and easy access to diverse products. The use of modular reaction sequence $\left(\mathrm{MRS}_{\mathrm{s}}\right)$ in this context is a useful way of creating diverse scaffolds ${ }^{1}$. In $\mathrm{MRS}_{\mathrm{s}}$ technique, a reactive intermediate is generated in situ, which can be reacted further with a range of different reaction paths, giving rise to a wide variety of scaffolds. An example of the use of $\mathrm{MRS}_{\mathrm{s}}$ is the coupling of in situ 1,3-dithiolate from amine and $\mathrm{CS}_{2}$ in the presence of suitable base with a range of different reaction partners ${ }^{2}$, including either 1,2-electrophile or 1,4-electrophiles. The 1,4-napthoquinone structure is common for many natural products. These compounds have been found to posses numerous biological activities such as antifungal $^{3}$, antibacterial ${ }^{4}$, anticancer ${ }^{5}$, antimalerial ${ }^{6}$ and antiparasitic activities ${ }^{7}$. Benzoquinones fused with heterocycles such as 1,3-dithioles (A) have been widely used as new material for super conducting, optical and electronic switching properties ${ }^{8}$. Tetrathiofulvalenes having 1,3-dithiole moiety (e.g., B and $\mathbf{C}$ ) are one of the most important class of organic compound having highly conducting and super conducting properties ${ }^{9}$.<smiles>CC1=COC(N)=C(C#N)C12SC1=C(S2)C(=O)c2ccccc2C1=O</smiles>

A<smiles>C1=CSC(=C2SC=CS2)S1</smiles>

B<smiles>O=C1C2=C(SC(=C3SC4=C(S3)C(=O)c3ccccc3C4=O)S2)C(=O)c2ccccc21</smiles>

C 
In search for agents with better pharmacological properties, wider activity range, better optoelectronic properties, it seemed quite promising to incorporate two " $\mathrm{S}$ " hetero atoms into the heterocycle attached to the napthoquinone.

\section{Experimental}

Instruments: The chemicals were purchased from Spectrochem and Hi-Media and were used as such. The ${ }^{1} \mathrm{H}$ and ${ }^{13} \mathrm{C}$ NMR spectra were recorded with Bruker instruments. Melting point was determined in a metal bath; uncorrected. IR Spectra: Spectrum 2 (Perkin-Elmer) spectrometer; LC/MS: Micromass (Water) apparatus; HRMS: Micromass-Q-TOF spectrometer. Elemental analyses: Thermo-Finnigton-Flash-EA-1112 analyzer.

\section{General Procedure for the preparation of $\mathbf{4 a}-\mathbf{4 g}$}

To a mixture of amine $(2.6 \mathrm{mmol})$ and $\mathrm{K}_{2} \mathrm{CO}_{3}(5.2 \mathrm{mmol})$ in $20 \mathrm{~mL}$ of water, $0.2 \mathrm{~mL}$ of $\mathrm{CS}_{2}$ (3.12 mmol) was added drop wise in a period of 30 mins at room temperature after the addition was complete, the mixture was stirred for several hours. Then the reaction mixture was cooled to $0{ }^{\circ} \mathrm{C}$ and a solution of $0.534 \mathrm{~g}$ 2,3-dichloro-1,4-napthaquinone (2.34 mmol) in $20 \mathrm{~mL}$ of $\mathrm{CH}_{2} \mathrm{Cl}_{2}$ was added drop wise. After the addition, stirring was continued until the reaction was complete (TLC). The organic layer was separated and the aqueous phase was extracted with $\mathrm{CH}_{2} \mathrm{Cl}_{2}(3 \times 10 \mathrm{~mL})$. The combined layers were dried over anhydrous $\mathrm{Na}_{2} \mathrm{SO}_{4}$, filtered and the solvent was evaporated in vacuo. The residue was purified by column chromatography using ethyl acetate/ petroleum ether as eluent.

\section{Modified procedure $\mathbf{( 4 g )}$}

To a mixture of amine $(2.6 \mathrm{mmol})$ and $\mathrm{K}_{2} \mathrm{CO}_{3}(5.2 \mathrm{mmol})$ in $25 \mathrm{~mL}$ of water and DMF ( 4:1), $0.2 \mathrm{~mL}$ of $\mathrm{CS}_{2}(3.12 \mathrm{mmol})$ was added drop wise in a period of 30 mins at room temperature, after the addition was complete, the mixture was stirred for several hours. Then the reaction mixture was cooled to $0{ }^{\circ} \mathrm{C}$ and a solution of $0.534 \mathrm{~g}$ 2,3-dichloro-1,4napthaquinone $(2.34 \mathrm{mmol})$ in $20 \mathrm{~mL}$ of $\mathrm{CH}_{2} \mathrm{Cl}_{2}$ was added drop wise. After the addition, stirring was for continued until the reaction was complete (TLC). The reaction mixture was worked up and the product was separated as earlier.

\section{Spectral and analytical data}

\section{2-Methyliminonaphtho[2,3-d][1,3] dithiole-4,9-dione (4a)}

${ }^{1} \mathrm{H}$ NMR (200 MHz, $\left.\mathrm{CDCl}_{3}\right) \delta: 8.196-8.151$ (m, 2H), $7.853-7.808(\mathrm{~m}, 2 \mathrm{H}), 3.327(\mathrm{~s}, 3 \mathrm{H}) .{ }^{13} \mathrm{C}$ NMR (50 MHz, $\left.\mathrm{CDCl}_{3}\right) \delta: 176.347,175.841,160.340,143.80,143.053,134.910,134.848$, 132.205, 131.852, 128.077, 127.973, 29.933. IR (KBr), $\gamma\left(\mathrm{cm}^{-1}\right):$ 1642.05, 1383.80, 708.32. LCMS: $\mathrm{m} / \mathrm{z}$ calcd. for $\mathrm{C}_{12} \mathrm{H}_{7} \mathrm{NO}_{2} \mathrm{~S}_{2} \mathrm{Na}\left(\mathrm{M}^{+}+\mathrm{Na}\right)$, 283.98; found 283.99. Anal.: Calcd. for $\mathrm{C}_{12} \mathrm{H}_{7} \mathrm{NO}_{2} \mathrm{~S}_{2}$ (M. W. 261.32) C, 55.15; H, 2.70; N, 5.36; found: C, 54.98; H, 2.73; N, 5.29.

\section{2-Butyliminonaphtho[2,3-d][1,3] dithiole-4,9-dione (4b)}

${ }^{1} \mathrm{H}$ NMR (200MHz, $\left.\mathrm{CDCl}_{3}\right), \delta: 8.16-8.11(\mathrm{~m}, 2 \mathrm{H}), 7.8-7.75(\mathrm{~m}, 2 \mathrm{H}), 3.28(\mathrm{t}, J=6.8 \mathrm{~Hz}$, 2H), $1.83-1.68$ (m, 2H), $1.53-1.35$ (m, 2H), 0.96 (t, $J=7.2 \mathrm{~Hz}, 3 \mathrm{H}) .{ }^{13} \mathrm{C}$ NMR: $(50 \mathrm{MHz}$, $\left.\mathrm{CDCl}_{3}\right), \delta: 176.232,175.686,155.592,143.965,143.205,134.357,134.308,134.226$, 132.111, 132,041, 127.218, 127.163, 59.426, 31.949, 20.576, 13.847. IR (KBr), $\gamma\left(\mathrm{cm}^{-1}\right)$ : 1640.11, 1384.89, 705.13. Mass (EI-MS): $\mathrm{m} / \mathrm{z}$, calcd. for $\mathrm{C}_{15} \mathrm{H}_{13} \mathrm{NO}_{2} \mathrm{~S}_{2} 303.0388\left(\mathrm{M}^{+}\right)$ found 303.0380. Anal.: calcd. for $\mathrm{C}_{15} \mathrm{H}_{13} \mathrm{NO}_{2} \mathrm{~S}_{2}$ (M. W. 303) C, 59.4; H, 4.29; N, 4.62; found: C, 59.23; H, 4.27; N, 4.53. 
2-Cyclohexyliminonaphtho[2,3-d][1,3] dithiole-4,9-dione (4c)

${ }^{1} \mathrm{H}$ NMR (200 MHz, $\mathrm{CDCl}_{3}$ ), $\delta: 8.16-8.10$ (m, 2H), $7.80-7.74(\mathrm{~m}, 2 \mathrm{H}), 2.93-2.88(\mathrm{~m}$, $1 \mathrm{H}), 1.51-2.25(\mathrm{~m}, 10 \mathrm{H}) .{ }^{13} \mathrm{C}$ NMR $\left(50 \mathrm{MHz}, \mathrm{CDCl}_{3}\right), \delta: 176.009,175.693,162.800$, 143.863, 142.939, 134.247, 134.219, 131.976, 131.930, 127.132, 127.093, 69.033, 31.88, 25.263 and 24.396. IR (KBr), $\gamma\left(\mathrm{cm}^{-1}\right)$ : 1653.06, 1647.94, 1384.88, 1285.61, 1152.43, 796.92, 698.28. HRMS: $m / z$ calcd. for $\mathrm{C}_{17} \mathrm{H}_{16} \mathrm{NO}_{2} \mathrm{~S}_{2} 330.0622\left(\mathrm{M}^{+}+1\right)$; found 330.0612 .

\section{2-Phenyliminonaphtho[2,3-d][1,3] dithiole-4,9-dione (4d)}

${ }^{1} \mathrm{H}$ NMR (500 MHz, $\mathrm{CDCl}_{3}$ ), $\delta: 8.139-8.082$ (m, 2H), $7.767-7.752$ (m, 2H), $7.44-7.41$ (m, 2H), $7.234-7.22(\mathrm{~m}, 1 \mathrm{H}), 7.03-7.015(\mathrm{~m}, 2 \mathrm{H})$. LCMS: $\mathrm{m} / \mathrm{z}$ calcd. for $\mathrm{C}_{17} \mathrm{H}_{9} \mathrm{NO}_{2} \mathrm{~S}_{2} \mathrm{Na}$ $\left(\mathrm{M}^{+}+\mathrm{Na}\right.$ ), 345.99; found 346.0. Anal.: Calcd. for $\mathrm{C}_{17} \mathrm{H}_{9} \mathrm{NO}_{2} \mathrm{~S}_{2}$ (M.W. 323.39) C, 63.14; H, 2.81; N, 4.33; found C, 63.25; H, 2.78; N, 4.26.

\section{2-p-Tolyliminonaphtho[2,3-d][1,3] dithiole-4,9-dione (4e)}

${ }^{1} \mathrm{H}-\mathrm{NMR}\left(200 \mathrm{MHz}, \mathrm{CDCl}_{3}\right), \delta: 8.05-8.17$ (m, 2H), $7.79-7.74(\mathrm{~m}, 2 \mathrm{H}), 7.22(\mathrm{~d}, 2 \mathrm{H}, \mathrm{J}=$ $8.6 \mathrm{~Hz}), 6.95$ (d, $2 \mathrm{H}, \mathrm{J}=8.6 \mathrm{~Hz}), 2.37$ (s, 3H). ${ }^{13} \mathrm{C} \mathrm{NMR}\left(50 \mathrm{MHz}, \mathrm{CDCl}_{3}\right.$ ): 175.97, 175.59, 159.33, 147.88, 143.36, 143.05, 135.68, 134.67, 134.20, 131.85, 130.33, 129.36, 128.89, 127.05, 119.43 and 20.99. LCMS: Calcd. for $\mathrm{C}_{18} \mathrm{H}_{11} \mathrm{NO}_{2} \mathrm{~S}_{2} \mathrm{Na}\left(\mathrm{M}^{+}+\mathrm{Na}\right), 360.01$; found 360.0. Anal.: Calcd. for $\mathrm{C}_{18} \mathrm{H}_{11} \mathrm{NO}_{2} \mathrm{~S}_{2}$ (M.W. 337.41) C, 64.07; H, 3.29; N, 4.15; found C, 64.22; H, 3.24; N, 3.17.

\section{2-(4-Methoxyphenylimino)naphtho[2,3-d] [1,3] dithiole-4,9-dione (4f)}

${ }^{1} \mathrm{H}$ NMR (200MHz, $\mathrm{CDCl}_{3}$ ), $\delta: 8.12$ - 8.09 (m, 2H), 7.79 - $7.75(\mathrm{~m}, 2 \mathrm{H}), 7.04-6.92(\mathrm{~m}, 4 \mathrm{H})$, 3.84 (s, 3H). ${ }^{13} \mathrm{C}$ NMR (50 MHz, $\left.\mathrm{CDCl}_{3}\right), \delta: 175.65,158.16,157.52,143.63,143.52$, 134.17, 131.88, 127.05, 120.96, 114.83 and 55.42. IR (KBr), $\gamma$ in $\mathrm{cm}^{-1}: 1647.34,1611.59$, 1586.08, 1502.71, 1384.90, 1283.82, 1247.38, 1152.77, 1023.15, 837.17, 698.93. Mass (EIMS): $\mathrm{m} / \mathrm{z}$ calcd. for $\mathrm{C}_{18} \mathrm{H}_{11} \mathrm{NO}_{3} \mathrm{~S}_{2} 353.0180\left(\mathrm{M}^{+}\right)$; found 353.0201. Anal.: calcd. for $\mathrm{C}_{18} \mathrm{H}_{11} \mathrm{NO}_{3} \mathrm{~S}_{2}$ (M, W. 353) C, 61.18; H, 3.12; N, 3.97; Found: C, 61.20; H, 3.01; N, 3.90.

\section{2-(4-Chlorophenylimino)naphtho[2,3-d][1,3]dithiole-4,9-dione (4g)}

${ }^{1} \mathrm{H}$ NMR $\left(200 \mathrm{MHz}, \mathrm{CDCl}_{3}\right) \delta: 8.13(\mathrm{~m}, 2 \mathrm{H}), 7.78-7.76(\mathrm{~m}, 2 \mathrm{H}), 7.4(\mathrm{~d}, 8.8 \mathrm{~Hz}, 2 \mathrm{H}), 6.98$ $(\mathrm{d}, 8.8 \mathrm{~Hz}, 2 \mathrm{H}) .{ }^{13} \mathrm{C}$ NMR $\left(50 \mathrm{MHz}, \mathrm{CDCl}_{3}\right) \delta: 176.298,175.972,161.035,149.232$, 143.797, 143.267, 134.588, 132.133, 131.439, 130.867, 130.030, 129.442, 127.439, 126.501 and 121.289. IR $\left(\mathrm{cm}^{-1}\right)$ : 1659.73, 1608.21, 1582.72, 1549.87, 1482.35, 1453.79, 1384.92, 1342.33, 1307.41, 1286.78, 1251.68, 1154.43, 823.31, 698.86. Mass (EI-MS): $\mathrm{m} / \mathrm{z}$ calcd. for $\mathrm{C}_{17} \mathrm{H}_{8} \mathrm{ClNO}_{2} \mathrm{~S}_{2} 358.9655\left(\mathrm{M}^{+}+2\right)$ and $356.9684\left(\mathrm{M}^{+}\right)$; found 358.9650 and 356.9680 in the intensity ratio of 1:3. Anal.: calcd. for $\mathrm{C}_{17} \mathrm{H}_{8} \mathrm{NO}_{2} \mathrm{~S}_{2} \mathrm{Cl}$ (M.W. 357.5) C, 57.06; H, 2.23; N, 3.92; Cl, 9.93; found: C, 57.15; H, 2.19; N, 3.87; Cl, 9.45.

\section{Results and Discussion}

Despite continuous interest in 1,4-napthoquinones fused with heterocycles, only a limited number of napthaquinone-1,3-dithioles with low yield have been reported, no general approach to their synthesis has been proposed. We were interested in developing a general method for the synthesis of napthoquinone-1,3-dithioles using 2,3-dichloro-1,4napthoquinone, primary amine and $\mathrm{CS}_{2}$ under aqueous condition. Recently Yujin Li, Jianrong Gao et al., ${ }^{10}$ has reported the formation of napthoquinone-1,3-dithioles via 2,3dichloro-1,4-napthoquinone and amines involving $\mathrm{CS}_{2}$ in presence of $\mathrm{Et}_{3} \mathrm{~N}$ as a base. However this method was applicable only to aliphatic amines. Moreover, the yield of the 
products was not satisfactory in a few cases. Initially we studied the reaction of aniline to prepare $\mathrm{N}$-phenyl dithiocarbamates in the presence of inorganic base, since inorganic bases were more efficient for the conversion of arylamines to $\mathrm{N}$-aryl dithiocarbamates in aqueous medium. A rigorous study of the preparation of isothiocyanates via $N$-aryl or $N$-alkyl dithiocarbamates has also been reported by Weimin MO, Xinquar Hu et al., ${ }^{2}$ under different basic conditions. They have established that the use of $\mathrm{K}_{2} \mathrm{CO}_{3}$ as a base in biphasic system $\left(\mathrm{CH}_{2} \mathrm{Cl}_{2}-\mathrm{H}_{2} \mathrm{O}\right)$ provided a high-yielding method of dithiocarbamates. To evaluate the procedure for the potential scaling up capability, we used aniline as test substrate to scale up the synthesis of $N$-phenyl napthoquinone-1,3-dithiole. Surprisingly this test provided a highly efficient formation of corresponding napthoquinone-1,3-dithiole (Scheme 1). Thereafter, we investigated the substrate scope for this reaction using a series of aromatic as well as aliphatic amine and got excellent yields in all the examples. The results are summarized in Table 1.<smiles></smiles>

Scheme 1

Table 1. Reaction conditions ${ }^{\mathrm{a}}$ and yields of naphtha-[2,3- $d$ ]-1,3-dithiole-4,9-diones

\begin{tabular}{ccccccc}
\hline Entry & 2 & $\mathrm{R}$ & Time, $\mathrm{h}$ & 4 & $\begin{array}{c}\text { M. P. of } \\
4,{ }^{\circ} \mathrm{C}\end{array}$ & $\begin{array}{c}\text { Yield, \% } \\
\mathrm{CH}_{2} \mathrm{Cl}_{2}-\mathrm{H}_{2} \mathrm{O}\end{array}$ \\
\hline 1 & $\mathbf{2 a}$ & $\mathrm{CH}_{3}-$ & 1 & $\mathbf{4 a}$ & 153.5 & 86.3 \\
2 & $\mathbf{2 b}$ & $\mathrm{CH}_{3} \mathrm{CH}_{2} \mathrm{CH}_{2} \mathrm{CH}_{2}-$ & 1 & $\mathbf{4 b}$ & 102.0 & 78.5 \\
3 & $\mathbf{2 c}$ & Cyclohexyl & 1 & $\mathbf{4 c}$ & 158.0 & 82.1 \\
4 & $\mathbf{2 d}$ & Phenyl & 2 & $\mathbf{4 d}$ & 166.0 & 67.5 \\
5 & $\mathbf{2 e}$ & p-Tolyl & 2 & $\mathbf{4 e}$ & 171.5 & 73.4 \\
6 & $\mathbf{2 f}$ & 4-Methoxyphenyl & 2 & $\mathbf{4 f}$ & 181.0 & 75.3 \\
7 & $\mathbf{2 g}$ & 4-Chlorophenyl & 3 & $\mathbf{4 g}$ & 207.0 & 31.4 \\
\hline
\end{tabular}

${ }^{a}$ All the reactions are carried out at room temperature. ${ }^{b} \mathrm{In}_{\mathrm{CH}_{2}} \mathrm{Cl}_{2}-\mathrm{H}_{2} \mathrm{O}-\mathrm{DMF}$

Aliphatic primary amines, linear or branched and most aromatic primary amines gave excellent yield $(\approx 80 \%)$, but poor efficiency of the method was noted for the strongly electron-deficient aryl amines. Poor solubility of such amines in water may be one of the reasons. To overcome this problem we used DMF as co-solvent. The DMF/ $\mathrm{H}_{2} \mathrm{O}$ (1:4)$\mathrm{CH}_{2} \mathrm{Cl}_{2}$ solvent system was found to be good.

It may be presumed that the dithiodianion (3, Scheme 1) intermediate is generated from $\mathrm{CS}_{2}$ and primary amine in presence of base initially. Subsequently this dianion undergoes activated nucleophilc substitutions (Michael addition and then elimination of $\mathrm{HCl}$ ) at $\mathrm{C}-2$ and C-3 of 2,3-dichloro-1,4-napthoquinone successively to furnish the expected napthoquinone-1,3-ditholes.

All the products have been characterised by UV, FTIR, ${ }^{1} \mathrm{H}$ NMR, ${ }^{13} \mathrm{C}$ NMR and Mass spectroscopic analyses. In conclusion, we report a MCR of a primary amine (aromatic or aliphatic), 2,3-dichloro-1,4-napthoquinone and carbon disulfide to furnish napthoquinone-1,3dithioles in reasonable to good yields under environmentally friendly conditions. The procedure of the reactions involving aromatic primary amines having electron withdrawing group are a little modified and carried out in DMF- $\mathrm{H}_{2} \mathrm{O}-\mathrm{CH}_{2} \mathrm{Cl}_{2}$ solvent system to obtain better yield. 


\section{Acknowledgement}

The authors are grateful to UGC for the financial support. Ref No: 42-259/2013(SR) dt. $12 / 03 / 2013$

\section{References}

1. $\quad$ Ruijter E, Scheffelaar R and Orru R V A, Angew Chem Int Ed., 2011, 50(28), 62346246; DOI:10.1002/anie.201006515

2. Nan S, Bin L, Jianping S, Wiemein M, Baoxaing $H$, Zhenlu $S$ and Xinquan $H$, Beilstein J Org Chem., 2012, 8, 61-70; DOI:10.3762/bjoc.8.6

3. Sacau E P, Estevez-Braun A, Ravelo A G, Ferro E A, Tokuda H, Mukainaka T and Nishino H, Bioorg Med Chem Lett., 2003, 11(4), 483-485; DOI:10.1016/S0960894X(00)00696-X

4. Salmon-Chemin L, Buisine E, Yardley V, Kohler S, Debreu M A, Landry V, Sergheraert C, Croft S L, Krauth-Seigel R L and Davioud-Charvet E, J Med Chem., 2001, 44(4), 548-565; DOI:10.1021/jm001079l

5. Tandon V K, Chhor R B, Sing R V, Rai S and Yadav D B, Bioorg Med Chem Lett., 2004, 14(5), 1079-1083; DOI:10.1016/j.bmcl.2004.01.002

6. Goulart M D F, Zani C L, Tonholo J, Freitas L R, Abreu F C de, Oliveira A B, Raslan D S, Starling S and Chiari E, Bioorg Med Chem Lett., 1997, 7, 2043-2048; DOI:10.1016/S0960-894X(97)00354-5

7. Fujiwara A, Mori T, Lida A, Ueda S, Hano Y, Nomura T, Tokuda H and Nishino H, $J$ Nat Prod., 1998, 61(5), 629-632; DOI:10.1021/np9800147

8. a) Konstantinova L S, Rakitin O A and Rees C W, Chem Rev., 2004, 104(5), 26172630; DOI:10.1021/cr0200926; b) Attanasi O A, Crescentini L D, Favi G, Filippone P, Giorgi G, Mantellini F, Moscatelli G and Behalo M S, Org Lett., 2009, 11(11), 2265-2268; DOI:10.1021/ol900545v; c) Wang F, Cai S, Wang Z and Xi C, Org Lett., 2011, 13(12), 3202-3205; DOI:10.1021/ol2011105; d) Tanaka K, Wada A and Noguchi K, Org Lett., 2006, 8(5), 907-909; DOI:10.1021/ol053044r; e) Nakano K, Patsumi G and Nozaki K, J Am Chem Soc., 2007, 129(49), 15116-15117; DOI:10.1021/ja076056b; f) Hagooly A and Rozen S, J Org Chem., 2004, 69(25), 8786-8788; DOI:10.1021/jo0485280; g) Shi L, Liu X, Zhang H, Jiang Y and Ma D, $J$ Org Chem., 2011, 76(10), 4200-4204; DOI:10.1021/jo200535e

9. a) Bendikov M, Wudl F and Perepichka D F, Chem Rev., 2004, 104(11), 4891-4946; DOI:10.1021/cr030666m b) Nielser M B, Lomholt C and Becher J, Chem Soc Rev., 2000, 29,153-164; DOI:10.1039/A803992E

10. Huang H, Han J, Xu F, Li Y, Dong H, Yu W and Gao J, Chem Lett., 2013, 42(8), 921-923; DOI: 10.1246/cl.130330 